\title{
REDUCTION OF NITRIC OXIDE WITH CARBONACEOUS MATERIALS FROM PEAT
}

\begin{abstract}
E. L. Schultz ${ }^{\mathrm{a}}$,
R. F. P. M. Moreira ${ }^{a}$, and H. J. Joséa, b

${ }^{\mathrm{a}}$ Universidade Federal de Santa Catarina Depto. de Eng. Química e Eng. de Alimentos Campus Universitário CP. 476, Florianópolis, Santa Catarina, Brasil bhumberto@enq.ufsc.br ABSTRACT
The direct NO reduction to produce $\mathrm{N}_{2}$ and $\mathrm{CO}_{2}$ using carbonaceous materials, chars and
activated carbons, was studied. Chars were prepared from peat by pyrolysis, at temperatures
ranging from $873 \mathrm{~K}$ to $1073 \mathrm{~K}$. Activated carbons were prepared by the physical activation
of chars with steam, in a steel reactor, at $1073 \mathrm{~K}$ for 12 minutes, 25 minutes and 45
minutes. The kinetics of NO reduction using chars and activated carbons produced at
different experimental conditions were evaluated at different temperatures in the range
$623-723 \mathrm{~K}$. The gaseous products were essentially $\mathrm{CO}_{2}$ and $\mathrm{N}_{2}$ and the amount of $\mathrm{CO}$
produced was negligible. The effect of the temperature on the kinetics of reduction was
also evaluated and the relationship between the rate constant and the temperature showed
an Arrhenius dependence. Activation energies of the $\mathrm{NO}$ reduction were in the range 6.75
to $7.97 \mathrm{kcal} . \mathrm{mol}^{-1}$ for the chars and in the range 8.14 to $9.52 \mathrm{kcal} . \mathrm{mol}^{-1}$ for the activated
carbons.

Keywords: reduction, nitric oxide, reactivity.
\end{abstract}

\section{NOMENCLATURE}

$\mathrm{C}_{\mathrm{N} 2} \quad \mathrm{~N}_{2}$ concentration in the outlet of the reactor, moles. $L^{-1}$

$\mathrm{C}_{\mathrm{NO}} \quad \mathrm{NO}$ concentration in the inlet of the reactor, moles. $\mathrm{L}^{-1}$

$\mathrm{E}_{\mathrm{a}} \quad$ activation energy, kcal.mol $^{-1}$

$\mathrm{E}_{0} \quad$ adsorption potencial

$\mathrm{F}_{\mathrm{NO} 0} \quad \mathrm{NO}$ flux in the inlet, mol.min ${ }^{-1}$

$\mathrm{k} \quad$ constant of reaction rate, $\mathrm{mol}^{-1} \mathrm{~g}^{-1} \cdot \mathrm{min}^{-1} \cdot \mathrm{atm}^{-1}$

$\mathrm{k}_{0} \quad$ frequency factor, mol. $\mathrm{g}^{-1} \cdot \mathrm{min}^{-1} \cdot \mathrm{atm}^{-1}$

$\mathrm{L}_{\mathrm{m}} \quad$ micropore width, $\mathrm{nm}$

$\mathrm{pH}_{\mathrm{pzc}} \quad$ point of zero charge

$\mathrm{p}_{\mathrm{NO}} \quad$ NO partial pressure

$\mathrm{r}_{\mathrm{NO}} \quad$ rate of NO reduction, mol. $\mathrm{g}^{-1} \cdot \mathrm{min}^{-1}$

$\mathrm{R}$ ideal gas law constant, $1.987 \mathrm{cal} \cdot \mathrm{mol}^{-1} \cdot \mathrm{K}^{-1}$

$\mathrm{T}$ temperature, $\mathrm{K}$

W carbon mass in the sample, $g$

$\mathrm{W}_{0} \quad$ micropore volume, $\mathrm{cm}^{3} \cdot \mathrm{g}^{-1}$

$\mathrm{X}_{\mathrm{NO}} \quad$ NO conversion

\section{INTRODUCTION}

The air pollution is the main environmental problem associated with the combustion of fossil fuels due to the emission of pollutants, such as nitrogen oxides $\left(\mathrm{NO}_{\mathrm{x}}\right)$, sulfur dioxide $\left(\mathrm{SO}_{2}\right)$, carbon monoxide $(\mathrm{CO})$, carbon dioxide $\left(\mathrm{CO}_{2}\right)$, volatile organic compounds (VOC) and particulate matter (PM).

The nitrogen oxides have received increasing attention since they are contributors to the formation of acid deposition and photochemical smog. Several techniques can be used to decrease the emission of nitrogen oxides, such as modifications in the combustion process, modification in the fuel, and post-combustion treatments. Selective catalytic reduction (SCR) of $\mathrm{NO}_{\mathrm{x}}$ with ammonia, selective noncatalytic reduction (SNCR) with ammonia and the catalytic decomposition of $\mathrm{NO}$ are typical postcombustion processes (Muzio and Quartucy, 1997, Yamashita, 1996).

Besides these post-combustion techniques, the reduction of $\mathrm{NO}$ using carbonaceous materials can be effective under suitable operating conditions. Carbon materials are suitable reductors due to the simplicity of the process, low cost and the elimination of the environmental problem caused by the release of these gases into the atmosphere (Bueno-López et al., 2002).

The aim of this work is to study the reaction of direct reduction of $\mathrm{NO}$ to produce $\mathrm{N}_{2}$ and $\mathrm{CO}_{2}$, at different temperatures, using chars and activated carbons obtained from peat as reducing agents.

\section{EXPERIMENTS}

The reduction of $\mathrm{NO}$ to produce $\mathrm{N}_{2}$ and $\mathrm{CO}_{2}$ using chars and activated carbons was studied in a differential fixed bed reactor, at total pressure of $1 \mathrm{~atm}$. The chars were prepared by pyrolysis under nitrogen atmosphere, at $873 \mathrm{~K}, 973 \mathrm{~K}$ and $1073 \mathrm{~K}$, designated as TP600, TP700 and TP800, 
respectively. The activated carbons were prepared from TP800 in a reaction furnace, by steam activation at $1073 \mathrm{~K}$ for 12,25 and 45 minutes, and they were designated as TA12, TA25 and TA45, respectively.

The materials were characterized by measuring surface areas, pore size distributions and point of zero charge $\left(\mathrm{pH}_{\mathrm{pzc}}\right)$. The surface areas and pore size distributions were determined by $\mathrm{N}_{2}$ adsorption at $77 \mathrm{~K}$ in an automatic multi-point volumetric apparatus (Autosorb 1C Quantachrome). The surface areas were calculated using the classical Brunauer-Emmett-Teller (BET) equation (Marsh, 1994). The method proposed by Barret, Joyner and Halenda (1951) was used to evaluate the pore size distribution.

The $\mathrm{pH}_{\mathrm{pzc}}$ of the carbons was measured by mixing $1 \mathrm{~g}$ of carbon with $20 \mathrm{~cm}^{3}$ of $\mathrm{CO}_{2}$-free distilled water. The slurry was kept in a plastic bottle and shaken periodically for 1-2 days until the $\mathrm{pH}$ of the slurry was taken to be the $\mathrm{pH}_{\mathrm{pzc}}$ of the solid (Moreno-Castilla et al., 2001).

The reactions were carried out in a differential fixed bed reactor. The amount of carbonaceous materials used in the experiments was about $1 \mathrm{~g}$ and the reactions were carried out at different temperatures $(623 \mathrm{~K}-723 \mathrm{~K})$, maintaining the flux of gas constant at the inlet of the reactor at $50 \mathrm{~cm}^{3} \mathrm{~N} / \mathrm{min}$. The reactant gas used was a standard mixture of $5.0 \%$ of $\mathrm{NO}$ in $\mathrm{He}$.

The reaction system (Fig. 1) was connected to a gas chromatograph equipped with two columns (Molecular Sieve 5A and a Porapak Q) and a thermal conductivity detector.

\section{RESULTS AND DISCUSSION}

\section{Characterization of the Carbonaceous Materials}

The $\mathrm{N}_{2}$ adsorption/desorption isotherms for the chars and activated carbons are shown in Figs. 2 and 3, respectively. TP600 shows an isotherm which is typical of a non-porous solid, while TA25 and TA45 presented a type IV isotherm with hysteresis loop indicating the presence of mesopores.

The chemical and textural characterization results of the carbonaceous materials are listed in Tab. 1. The chars and activated carbons showed alkaline chemical character. The BET surface area and the micropores volume $\left(\mathrm{W}_{0}\right)$ of the chars increased with the pyrolysis temperature, as also observed for activated carbons. The micropores width $\left(\mathrm{L}_{\mathrm{m}}\right)$ of all the carbonaceous materials is higher than the kinetic diameter of NO, $0.317 \mathrm{~nm}$ (Neathery et al., 1997), allowing its diffusion into the micropores.

The data of the pore size distribution showed that the micropores fraction increases as the temperature of pyrolysis increases while mesoand macropores fractions of the chars decreases as the temperature of pyrolysis increases. The fraction of meso- and macropores also increases by activation of TP800, except for the activation for 45 min (TA45). However, TA45 shows the higher micropore volume $\left(\mathrm{W}_{0}\right)$ than TP800. So, TA45 is more porous than TP800, but showing higher fraction of meso and macropores than TP800.

The activation of TP800 for $12 \mathrm{~min}$, to produce TA12, resulted in a great increase $(>60 \%)$ in the micropore volume and a small increase (about 5\%) in the surface area.

According to Tab. 1, the ash content increases with the increase in pyrolysis temperature, whereas the oxygen content decreases. The increase in the ash content can be ascribed to the character not volatile of the inorganic residue, while the decrease in the oxygen content is a consequence of the removal of oxygenated fragments (Fuchsman, 1980). The activated carbons also showed an increase in the ash content with the increase in the oxidation degree, due to the consumption of the carbon. However, there is no direct correlation between the activation time and the oxygen content.

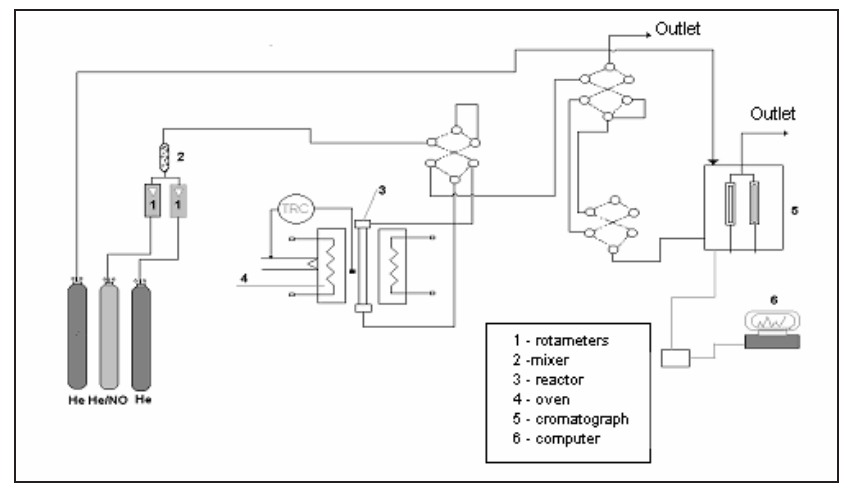

Figure 1. Experimental apparatus. 


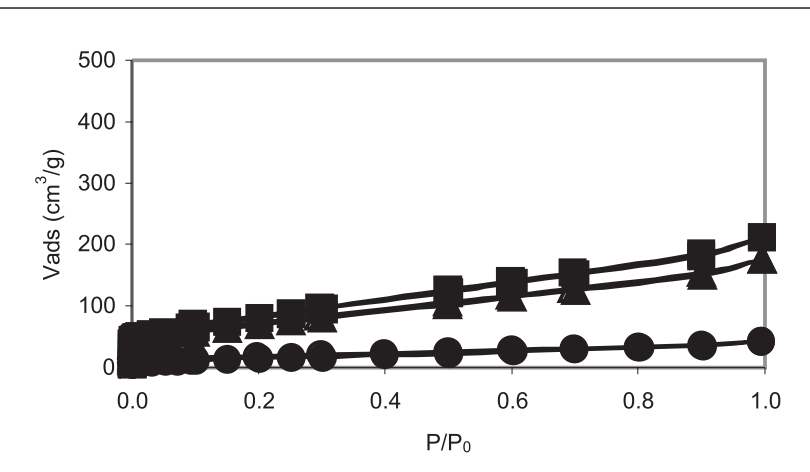

Figure 2. $\mathrm{N}_{2}$ adsorption and desorption curves for TP600 (circles), TP700 (triangles) and TP800 (squares). Closed symbols: adsorption; opened symbols: desorption.

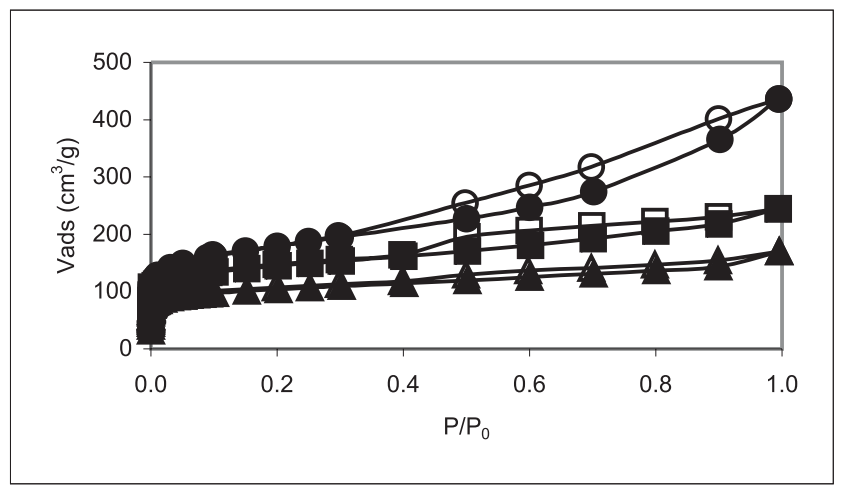

Figure 3. $\mathrm{N}_{2}$ adsorption and desorption curves for TA12 (triangles), TA25 (squares) and TA45 (circles). Closed symbols: adsorption; opened symbols: desorption.

Table 1. Characteristics of the carbonaceous materials studied.

\begin{tabular}{|c|c|c|c|c|c|c|c|}
\hline \multicolumn{2}{|c|}{ (1) } & TP600 & TP700 & TP800 & TA12 & TA25 & TA45 \\
\hline \multicolumn{2}{|c|}{ Point of zero charge } & 8.03 & 8.16 & 8.15 & 8.47 & 9.07 & 9.22 \\
\hline \multicolumn{2}{|c|}{ BET surface area, $\mathrm{m}^{2} \cdot \mathrm{g}^{-1}$} & 56.1 & 253.6 & 303.1 & 320.5 & 450.5 & 583.8 \\
\hline \multirow{3}{*}{$\begin{array}{l}\text { Dubinin- } \\
\text { Radushkevich } \\
\text { parameters }\end{array}$} & $\mathrm{W}_{0}, \mathrm{~cm}^{3} \cdot \mathrm{g}^{-1}$ & 0.016 & 0.079 & 0.090 & 0.147 & 0.201 & 0.237 \\
\hline & $\mathrm{E}_{0}, \mathrm{~kJ} \cdot \mathrm{mol}^{-1}$ & 10.89 & 13.32 & 12.42 & 13.85 & 12.80 & 11.15 \\
\hline & $\mathrm{L}_{\mathrm{m}}, \mathrm{nm}$ & 4.77 & 3.90 & 4.19 & 3.75 & 4.06 & 4.66 \\
\hline \multirow{3}{*}{$\begin{array}{l}\text { Pore size } \\
\text { distribution, } \%\end{array}$} & Micro & 32.41 & 51.39 & 55.94 & 75.92 & 66.95 & 47.03 \\
\hline & Meso & 55.95 & 40.90 & 38.01 & 18.30 & 27.76 & 43.52 \\
\hline & Macro & 11.64 & 7.71 & 6.05 & 5.78 & 5.29 & 9.45 \\
\hline \multirow{5}{*}{$\begin{array}{l}\text { Elementar } \\
\text { analysis, } \\
\% \text { weight } \\
\text { (dry basis) }\end{array}$} & Carbon & 54.72 & 58.91 & 58.44 & 58.87 & 53.18 & 50.83 \\
\hline & Nitrogen & 2.01 & 1.78 & 1.24 & 1.32 & 0.89 & 0.80 \\
\hline & Hydrogen & 2.32 & 1.87 & 1.23 & 1.44 & 1.23 & 1.04 \\
\hline & Sulfur & 0.00 & 0.00 & 0.00 & 0.00 & 0.00 & 0.00 \\
\hline & Oxygen & 16.73 & 12.98 & 9.26 & 4.85 & 9.05 & 7.06 \\
\hline \multirow{3}{*}{$\begin{array}{l}\text { Proximate } \\
\text { analysis, } \\
\% \text { weight (d. b.) }\end{array}$} & Volatile & 18.48 & 10.91 & 9.01 & 8.44 & 7.54 & 7.88 \\
\hline & Fixed carbon & 57.30 & 64.63 & 61.16 & 58.04 & 56.81 & 51.85 \\
\hline & Ash & 24.22 & 24.46 & 29.83 & 33.52 & 35.65 & 40.27 \\
\hline
\end{tabular}

$\mathrm{W}_{0}=$ micropore volume; $\mathrm{E}_{0}=$ adsorption potential; $\mathrm{L}_{\mathrm{m}}=$ micropore width.

\section{Reaction}

Preliminary tests showed that after a reaction time of $80 \mathrm{~min}$, the NO conversion was nearly constant. The determination of the kinetic was evaluated using the experimental data collected after 80 minutes. The results obtained were related with the NO conversion, according to Eq. (1).

$$
X_{N O} \frac{2 C_{N_{2}}}{C_{N O_{0}}}
$$

where: $\mathrm{X}_{\mathrm{NO}}=\mathrm{NO}$ conversion; $\mathrm{C}_{\mathrm{N} 2}=\mathrm{N}_{2}$ concentration in the outlet of the reactor, moles. $\mathrm{L}^{-1} ; \mathrm{C}_{\mathrm{NO} 0}=\mathrm{NO}$ concentration in the inlet of the reactor, moles. $\mathrm{L}^{-1}$.
The NO reduction was studied at temperatures in the range $623 \mathrm{~K}-723 \mathrm{~K}$ and the NO concentration in the inlet was $5.0 \%$. Figures 4-6 show the experimental data obtained from the NO reduction using the chars TP600, TP700 and TP800, respectively. Figures 7, 8 and 9 show the data of the activated carbons TA12, TA25 and TA45, respectively. 


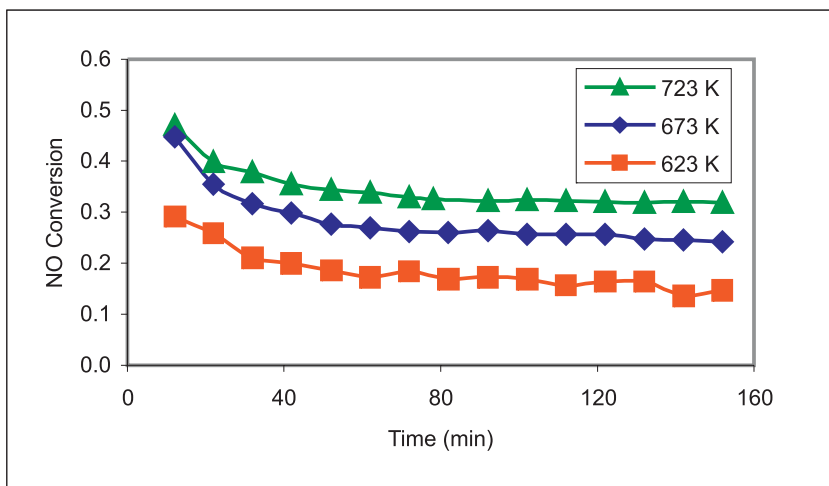

Figure 4. NO conversion for TP600 at different temperatures.

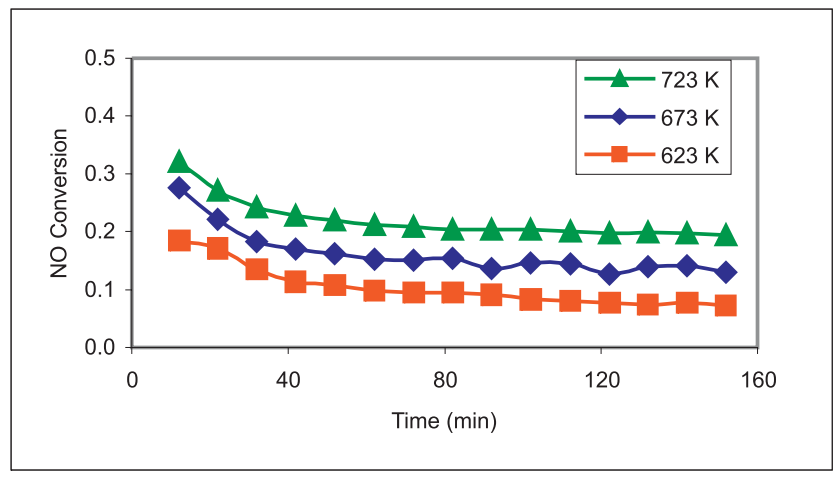

Figure 5. NO conversion for TP700 at different temperatures.

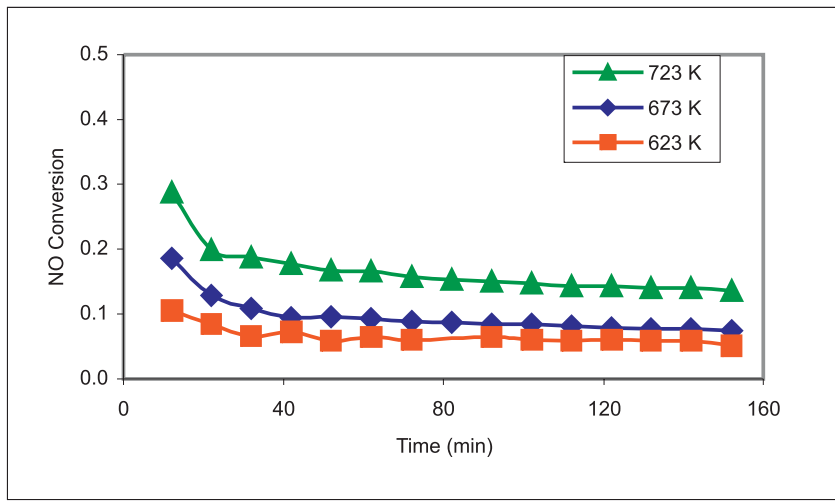

Figure 6. NO conversion for TP800 at different temperatures.

The rate of NO reduction was calculated according Eq. (2):

$$
r_{N O} \frac{F_{N O_{0}} X_{N O}}{W}
$$

where: $\mathrm{r}_{\mathrm{NO}}=$ rate of $\mathrm{NO}$ reduction, $\mathrm{mol} \cdot \mathrm{g}^{-1} \cdot \mathrm{min}^{-1}$; $F_{N O_{0}}=$ NO flux rate in the inlet, mol.min ${ }^{-1}$; $\mathrm{X}_{\mathrm{NO}}=\mathrm{NO}$ conversion; $\mathrm{W}=$ carbon mass in the sample, $\mathrm{g}$.

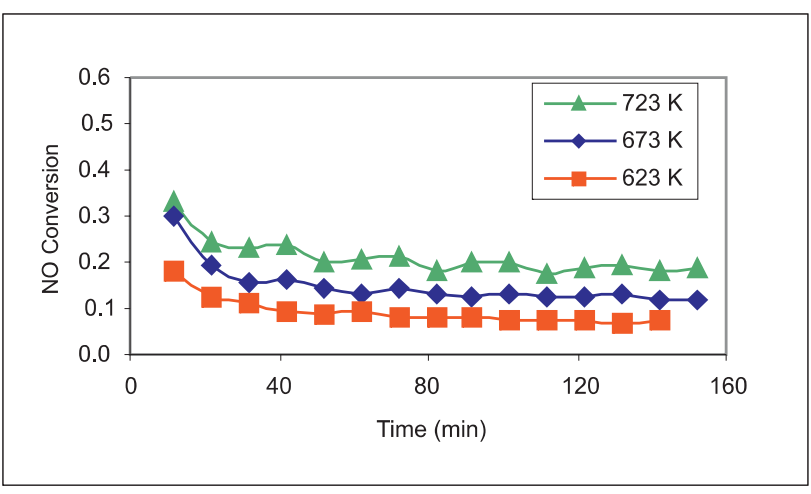

Figure 7. NO conversion for TA12 at different temperatures.

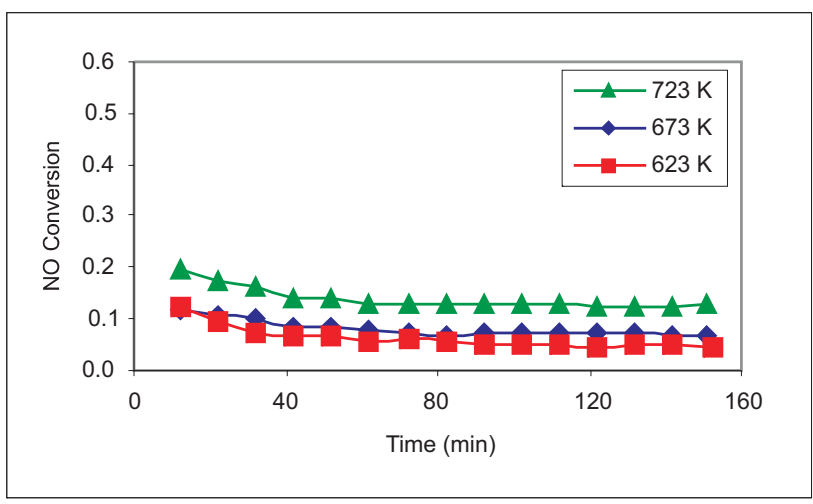

Figure 8. NO conversion for TA25 at different temperatures.

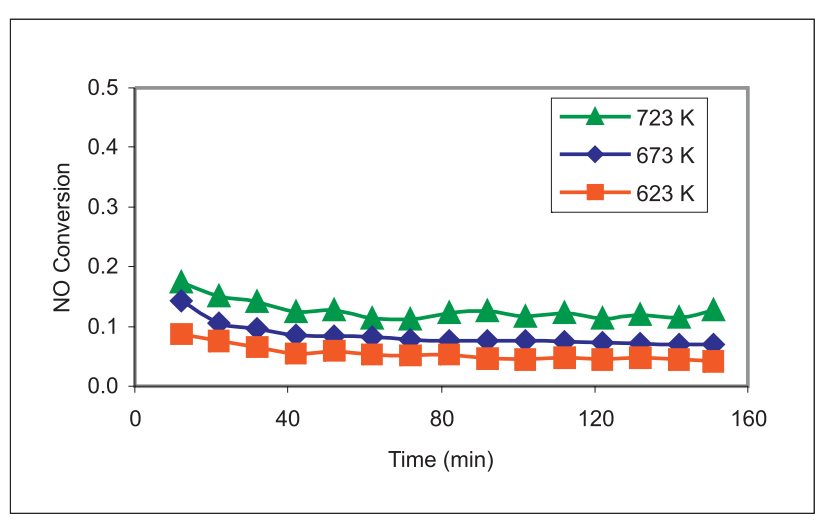

Figure 9. NO conversion for TA45 at different temperatures.

Since the carbon conversion was low, the rate of NO reduction depends only on the NO pressure. The reaction order in relation to $\mathrm{NO}$ was assumed to be first order, as previously reported by Aarna and Suuberg (1997) and Koepsel et al. (2002). The kinetic constant, k, was calculated according to Eq. (3):

$$
r_{N O}=k \cdot p_{N O}
$$


The dependency of the constant of the reaction rate with the temperature followed an Arrhenius behaviour (Eq. 4):

$$
k \quad k_{0} \exp ^{\S \square E_{a}} .
$$

where: $\mathrm{k}=$ constant of the reaction rate, mol.g $\mathrm{g}^{-1} \cdot \mathrm{min}^{-1} \cdot \mathrm{atm}^{-1} ; \mathrm{k}_{0}=$ frequency factor, mol.g${ }^{1} \cdot \mathrm{min}^{-1} \cdot \mathrm{atm}^{-1} ; \mathrm{E}_{\mathrm{a}}=$ activation energy, kcal. $\mathrm{mol}^{-1} ; \mathrm{R}$ = ideal gas law constant, $1.987 \mathrm{cal} \cdot \mathrm{mol}^{-1} \cdot \mathrm{K}^{-1}$; $\mathrm{T}=$ temperature, $\mathrm{K}$.

The activation energies and frequency factor of the reaction were obtained by linear regression of $\ln \mathrm{k}$ versus 1/T (Fig. 10), as shown in Tab. 2.

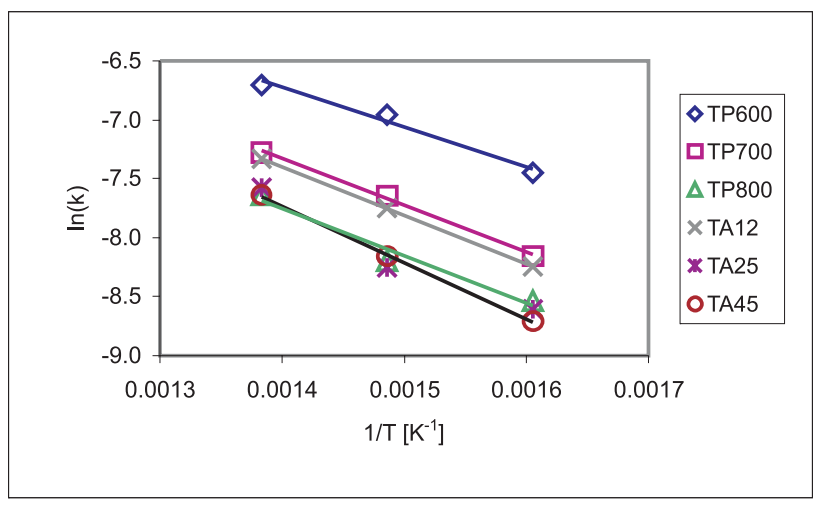

Figure 10. Arrhenius diagram for the carbonaceous materials.

Table 2. Activation energy and frequency factor of the NO reduction with the carbonaceous materials studied.

\begin{tabular}{c|c|c|c}
\hline Material & $\mathrm{k}_{0}$ & $\mathrm{E}_{\mathrm{a}}$ & $\mathrm{R}^{2}$ \\
\hline TP600 & 0.140 & 6.75 & 0.9795 \\
\hline TP700 & 0.168 & 7.87 & 0.9979 \\
\hline TP800 & 0.118 & 7.97 & 0.9665 \\
\hline TA12 & 0.189 & 8.14 & 0.9999 \\
\hline TA25 & 0.280 & 9.15 & 0.9524 \\
\hline TA45 & 0.360 & 9.52 & 0.9992 \\
\hline
\end{tabular}

$\mathrm{k}_{0}=\left[\mathrm{mol} \cdot \mathrm{g}^{-1} \cdot \mathrm{min}^{-1} \cdot \mathrm{atm}^{-1}\right], \mathrm{E}_{\mathrm{a}}=\left[\mathrm{kcal} \cdot \mathrm{mol}^{-1}\right]$

Calculating $\mathrm{k}$ from the data of $\mathrm{k}_{0}$ and $\mathrm{E}_{\mathrm{a}}$, shown in Table 2, from the Arrhenius' equation (Eq. 4 ), the data shown in Tab. 3 were obtained.

It can be observed (Tabs. 2 and 3) that TP600 is the most reactive char for the reduction of NO. This may be explained because TP600 was obtained under the less severe heat treatment, and probably has the highest amount of reactive sites (Aarna and Suuberg, 1997).
The peat char, TP600, showed higher reactivity for the NO reduction than the coal char used by Koepsel et al. (2002): about 59\% higher at $623 \mathrm{~K}$ and $45 \%$ higher at $673 \mathrm{~K}$. The activation energy obtained for the coal was slightly higher (8.20 kcal.mol ${ }^{-1}$ ) than that found for the TP600, but close to the other carbonaceous materials studied.

García and Mondragón (2004) reported that due to the radical nature of both reactants the activation energy of this reaction is close to zero.

The activation energy found by Illán-Gómez et al. (1993) for the reduction of NO with activated carbons is in the range 10.75 to $20.55 \mathrm{kcal}_{\mathrm{mol}}{ }^{-1}$, higher values than it was found in this work. The value of $10.75 \mathrm{kcal}_{\mathrm{mol}}^{-1}$ was found for an activated carbon with surface area (BET) of $457 \mathrm{~m}^{2} \cdot \mathrm{g}^{-1}$, value close to the surface area of TA25 $\left(450 \mathrm{~m}^{2} \cdot \mathrm{g}^{-1}\right)$, which showed an activation energy of $9.15 \mathrm{kcal}^{\mathrm{mol}} \mathrm{mo}^{-1}$ (Tab. 2).

Table 3. Constant of reaction rate $\left[\mathrm{mol} \cdot \mathrm{g}^{-1} \cdot \mathrm{min}^{-1} \cdot \mathrm{atm}^{-1}\right]$ for the different carbonaceous materials, calculated by Eq. (4).

\begin{tabular}{c|c|c|c}
\hline \multirow{2}{*}{ Material } & \multicolumn{3}{|c}{ Temperature } \\
\cline { 2 - 4 } & $623 \mathrm{~K}$ & $673 \mathrm{~K}$ & $723 \mathrm{~K}$ \\
\hline TP600 & $5.99 \times 10^{-04}$ & $8.98 \times 10^{-04}$ & $1.27 \times 10^{-03}$ \\
\hline TP700 & $2.91 \times 10^{-04}$ & $4.66 \times 10^{-04}$ & $7.01 \times 10^{-04}$ \\
\hline TP800 & $1.88 \times 10^{-04}$ & $3.04 \times 10^{-04}$ & $4.59 \times 10^{-04}$ \\
\hline TA12 & $2.64 \times 10^{-04}$ & $4.30 \times 10^{-04}$ & $6.55 \times 10^{-04}$ \\
\hline TA25 & $1.72 \times 10^{-04}$ & $2.97 \times 10^{-04}$ & $4.77 \times 10^{-04}$ \\
\hline TA45 & $1.64 \times 10^{-04}$ & $2.91 \times 10^{-04}$ & $4.76 \times 10^{-04}$ \\
\hline
\end{tabular}

\section{CONCLUSIONS}

The activation energies for the NO reduction using carbonaceous materials are in the range 6.75 to $9.52 \mathrm{kcal}^{\mathrm{mol}}{ }^{-1}$. These values agree with the values found in the literature. The carbonaceous material produced under the less severe thermal treatment showed the highest reactivity for the NO reduction. The peat char showed higher reactivity than coal char. The results showed that these carbonaceous materials from peat have high potential for the NO reduction.

\section{ACKNOWLEDGEMENTS}

E. L. Schultz is a PhD student supported by CAPES (Brazil). 


\section{REFERENCES}

Aarna, I, Suuberg, E. M., 1997, A review of the kinetic of the nitric oxide-carbon reaction, Fuel, Vol. 76, pp. 475-491.

Barret, E. P., Joyner, L. G., Halenda, P. P., 1951, The Determination of Pore Volume and Area Distributions in Porous Substances. I. Computations from Nitrogen Isotherms, Journal of the American Chemical Society, Vol. 73, pp. 373-380.

Bueno-López, A., García-García, C., SalinaMartinez de Lecea, C., McRae, C., Snape, C. E, 2002, Low-Cost Potassium-Containing Char Briquettes for $\mathrm{NO}_{\mathrm{x}}$ Reduction, Energy \& Fuels, Vol. 16, pp. 997-1003.

Fuchsman, C. H., 1980, Peat, industrial chemistry and technology, New York: Academic Press, Inc.

García, P. Mondragón, F., 2004, Reducción de Óxidos de Nitrógeno por Materiales Carbonosos, in: Rodríguez Reinoso, F., Adsorbentes en la Solución de Algunos Problemas Ambientales, Madrid, España: Ediciones CYTED. (in Spanish)

Illán-Gómez, M. J., Linares-Solano, A., Salinas-Martínez de Lecea, C., 1993, NO Reduction by Activated Carbons. 1. The Role of Carbon Porosity and Surface Area, Energy \& Fuels, Vol. 7, pp. 146-154.

Koepsel, J., Strassmann, D. S., Moreira, R. F. P. M., José, H. J., 2002, Estudo cinético da redução do monóxido de nitrogênio sobre coque, in: XIV Congresso Brasileiro de Engenharia Química, Natal, COBEQ 2002 - Anais, Vol. 01. (in Portuguese)

Marsh, H., 1994, Introduction to carbon science, New York: Butterworths.

Moreno-Castilla, C., Carrasco-Marín, F., Parejo-Pérez, C., López Ramón, M. V., 2001, Dehydration of methanol to dimethyl ether catalyzed by oxidized activated carbon with varying surface acidic character, Carbon, Vol. 39, pp. 869-875.

Muzio, L. J., Quartucy, G. C., 1997, Implementing NOx control: research to application, Progress in Energy and Combustion Science, Vol. 23, pp. 233-266.

Neathery, J. K., Rubel, A. M., Stencel, J. M., 1997, Uptake of $\mathrm{NO}_{\mathrm{x}}$ by activated carbons: bench-scale and pilot-plant testing, Carbon, Vol. 35, pp. 1321-1327.

Yamashita, T., 1996, $\mathrm{NO}_{\mathrm{x}}$ decomposition over different manganese oxides, Dissertation, Pensylvania State University. 